\title{
SODIUM NITROPRUSSIDE IN CHILDREN: OBSERVATIONS ON METABOLISM DURING NORMAL AND ABNORMAL RESPONSES
}

\author{
D.W. Davies, Leila Greiss, D. Kadar, D.J. Steward
}

SODIUM NITROPRUSSIDE $\left(\mathrm{Na}_{2} \mathrm{Fe}(\mathrm{CN})_{5}\right.$ ) was first used clinically in $1929 .{ }^{1}$ Since 1962 it has become increasingly popular to achieve controlled hypotension during anaesthesia. ${ }^{2-4}$ Previous publications have attested to its potency, efficacy and, with due precautions, its safety largely because of its evanescent action. Dosage during anaesthesia had been on an empirical basis depending on the degree and duration of hypotension required. Recently McDowall has suggested limiting the dose of sodium nitroprusside to $1.6 \mathrm{mg} / \mathrm{Kg} / \mathrm{hr}$. 5 Total dosages of sodium nitroprusside of $3 \mathrm{mg} / \mathrm{Kg}^{6}$ and $3.5 \mathrm{mg} / \mathrm{Kg}^{7}$ have been suggested.

Three deaths have been reported associated with sodium nitroprusside as a hypotensive agent during anaesthesia. ${ }^{6-8}$ Each death was associated with resistance to sodium nitroprusside. Tachyphylaxis and resistance to the drug in young people have been mentioned ${ }^{\text {n-11 }}$ but few details are available.

\section{Clinical Experience}

Since April 1974 sodium nitroprusside has been used at The Hospital for Sick Children, Toronto, to provide controlled hypotension during anaesthesia in over two dozen cases. Children aged two days to eighteen years have received sodium nitroprusside as a 0.01 per cent infusion for a variety of surgical procedures, but primarily for extensive and prolonged cranio-facial osteotomies. ${ }^{12}$

Apart from cases showing a normal response to sodium nitroprusside at doses below $3 \mathrm{mg} / \mathrm{Kg}$ we have observed two patients with a normal response but needing doses higher than $3 \mathrm{mg} / \mathrm{Kg}$, these patients exhibiting tachyphylaxis and one patient who died of cyanide intoxication. ${ }^{\top}$

Consequently we recognize and can define three responses to sodium nitroprusside in children: constant response, tachyphylaxis to and resistance to the drug. Besides the normal constant response to low doses $(<3 \mathrm{mg} / \mathrm{Kg})$ there exists constant response to high doses $(>3 \mathrm{mg} / \mathrm{Kg}$ ). Constant high dose response to, resistance to and tachyphylaxis to sodium nitroprusside are potentially lethal.

A normal response to sodium nitroprusside with doses less than $3 \mathrm{mg} / \mathrm{Kg}$ has not been associated with any clinical or metabolic abnormalities or difficulties.

A constant response to sodium nitroprusside with doses in excess of $3 \mathrm{mg} / \mathrm{Kg}$ has been associated with metabolic disturbances as shown in Figures 1 and 2. Each

From the Departments of Anaesthesia and Pharmacology, University of Toronto, Toronto, Canada.

Address reprints requests to: Dr. D.W. Davies, Department of Anaesthesia, The Hospital for Sick Children, 555 University Avenue, Toronto, Ontario. Canada M5G 1X8 


\section{G.W., WHITE MALE, 18 YEARS, $80 \mathrm{Kg}$}

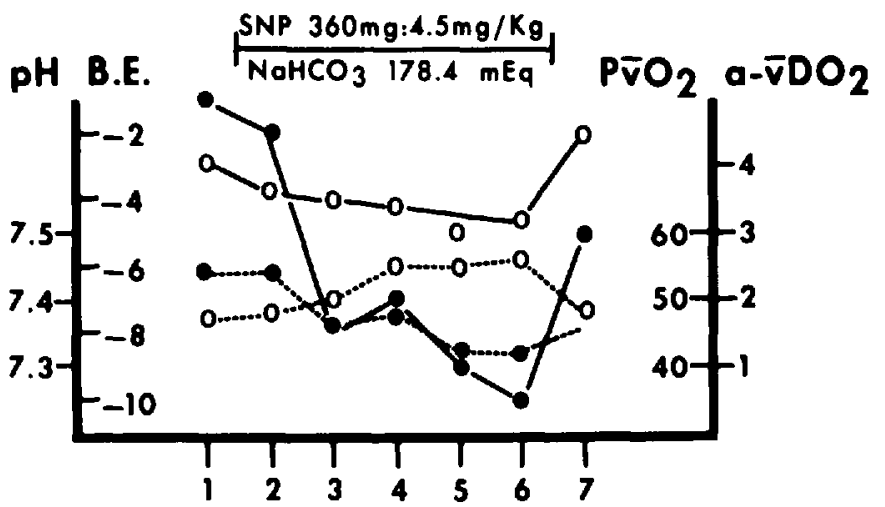

TIME IN HOURS

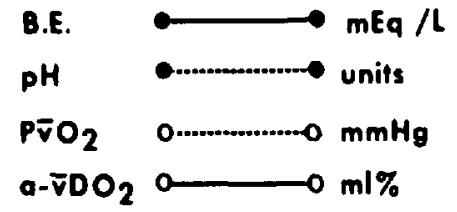

Figure 1. Changes in A-B Status to High Dose SNP.

\section{K.C., WHITE FEMALE, 16 YEARS, $60 \mathrm{Kg}$}
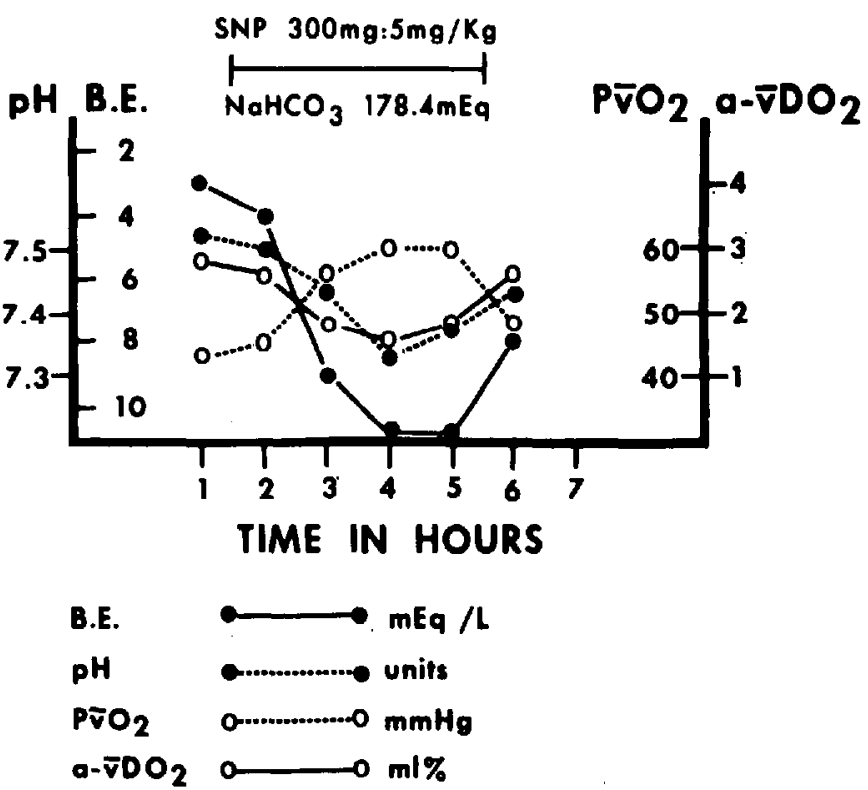

Figure 2. Changes in A-B Status to High Dose SNP. 
patient showed a rise in mixed venous oxygen tension $\left(\mathrm{P}_{\mathrm{O}_{2}}\right)$, a fall in arterialmixed venous oxygen content difference $\left(a-\bar{v} D_{\mathrm{O}_{2}}\right)$ and metabolic acidosis which persisted until the administration of sodium nitroprusside was discontinued despite buffering with 7.5 per cent sodium bicarbonate. This decrease in oxygen uptake and accompanying metabolic acidosis we believe represents cyanide intoxication of cellular cytochrome oxidases. Sodium nitroprusside reacts with haemoglobin to produce cyanmethaemoglobin ${ }^{13}$ reducing red cell oxygen transport. It is also a potent inhibitor of carbonic anhydrase ${ }^{14}$ and consequently red cell oxygen transport is further reduced.

Resistance to sodium nitroprusside is an inability to attain or to maintain safe minimal levels of systolic blood pressure even with increasing doses of sodium nitroprusside.

Patients who have shown resistance to sodium nitroprusside ${ }^{6-8}$ have exhibited this resistance very rapidly, that is within ten minutes. Each patient was a previously healthy male. The resistance to the drug persisted even with very high doses and with adjuvant methods to reduce blood pressure.

Our patient who died ${ }^{7}$ had severe metabolic acidosis, a lethal blood level of cyanide $(0.5 \mathrm{mg} \%)$, high urinary cyanide $(0.3 \mathrm{mg} \%)$ and undetectable levels of thiocyanate in blood or urine. The other three known deaths also had severe metabolic acidosis.

Tachyphylaxis to sodium nitroprusside is the ability to attain safe minimal levels of systolic blood pressure but needing increasing doses of the drug to maintain that response. We have experienced three such cases of tachyphylaxis. We suggest that the case of Merrifield and Blundell ${ }^{6}$ represents tachyphylaxis.

Our first case of tachyphylaxis occurred in a previously healthy 16-year-old white female. It's onset was gradual but well defined after 30 minutes of infusing sodium nitroprusside. The projected dose for the anticipated period of hypotension would have been in excess of $3 \mathrm{mgm} / \mathrm{Kg}$. We therefore discontinued the infusion. During the 30 minutes of the infusion the patient developed moderate metabolic acidosis which returned to normal 30 minutes after the drug was discontinued.

Our second case of tachyphylaxis was a 16-year-old white female. The dosage of sodium nitroprusside needed to maintain the same systolic pressure and the associated disturbance of her $\mathrm{P}_{\mathrm{O}_{2}}$ and a- $\nabla \mathrm{D}_{\mathrm{O}_{2}}$ during the infusion are shown in Figure 3. After 60 minutes of infusion of the drug it was stopped. During the ensuing two hours the patient was treated with 7.5 per cent sodium bicarbonate and allowed to recover. When her acid-base (A-B), $\mathrm{P}_{\mathrm{O}_{2}}$ and $\mathrm{a}-\mathrm{\nabla D} \mathrm{D}_{\mathrm{O}_{2}}$ were normal and stable, 25 per cent sodium thiosulphate $(150 \mathrm{mg} / \mathrm{Kg}$ ) was infused over 15 minutes. Following this infusion the patient was again rendered hypotensive to the same level of systolic and mean arterial pressure as before with a further infusion of sodium nitroprusside. Her dose response characteristics for this second infusion and her $\mathrm{P}_{\mathrm{O}_{2}}$ and $\mathrm{a}-\overline{\mathrm{v}} \mathrm{D}_{\mathrm{O}_{2}}$ during this period are shown in Figure 4.

A third case of tachyphylaxis in an 11-year-old previously healthy male showed a similar change in metabolic parameters during the infusion of sodium nitroprusside. Following an infusion of 25 per cent sodium thiosulphate $(150 \mathrm{mg} / \mathrm{Kg})$ 
M.M. WHITE FEMALE, 16 YEARS, $80 \mathrm{Kg}$ BEFORE SODIUM THIOSULPHATE

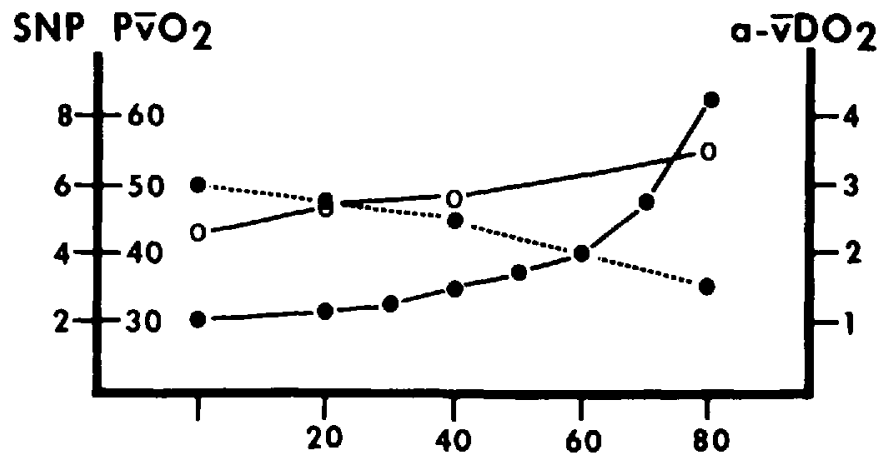

TIME IN MINUTES

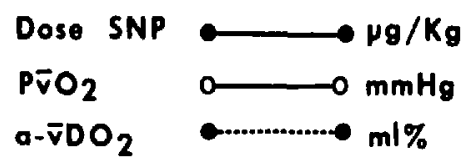

Figure 3. Oxygen Transport during Tachyphylaxis to SNP.

\section{M.M., WHITE FEMALE, 16 YEARS, $80 \mathrm{Kg}$}

AFTER SODIUM THIOSULPHATE

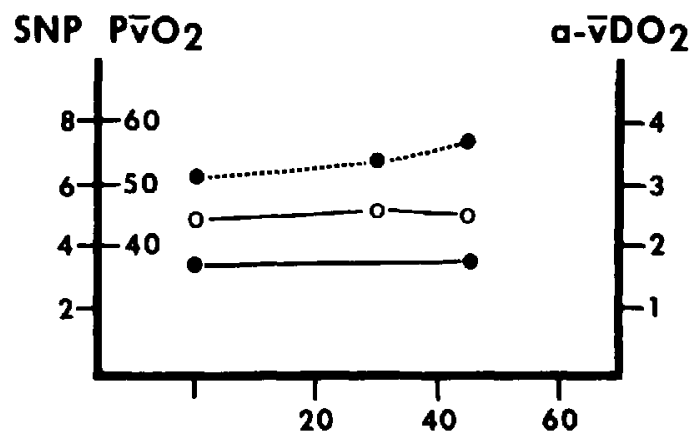

TIME IN MINUTES

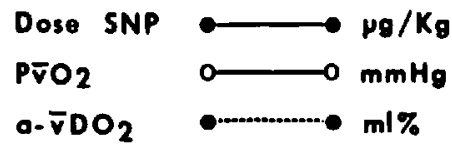

Figure 4. Oxygen Transport and Response to SNP after Sodium Thiosulphate Infusion. 


\section{K.O., WHITE MALE, II YEARS, $50 \mathrm{Kg}$}
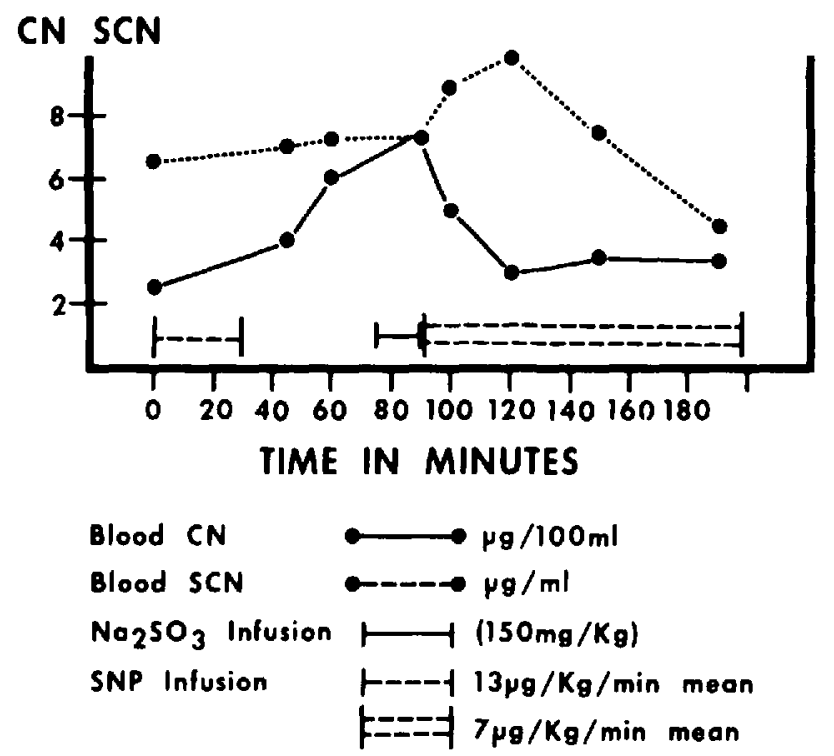

FIgure 5. Blood Cyanide and Thiocyanate Levels with SNP before and after Sodium Thiosulphate Infusion.

a second infusion of sodium nitroprusside was given to produce similar levels of hypotension. During this second infusion tachyphylaxis was significantly reduced and $A-B, \mathrm{P}_{\mathrm{O}_{2}}$ and $\mathrm{a}-\overline{\mathrm{v}} \mathrm{D}_{\mathrm{O}_{2}}$ remained normal. The blood levels of cyanide and thiocyanate (measured by modified Epstein ${ }^{15}$ and modified Boxer and Rickards ${ }^{16}$ methods) during sodium nitroprusside infusion before and after the sodium thiosulphate therapy are shown in Figure 5.

\section{METaBolism of Sodium Nitroprussme}

The metabolism of sodium nitroprusside is represented in Figure 6. The dynamics of each of the steps and the load capacity of the whole system is unknown. It is believed that the dynamics are such that the pool of free cyanide is kept very low even in the face of relatively large loads of cyanide or cyanide precursors. For this to be so the cyanide-thiocyanate pathways must be intact, i.e. there must be adequate amounts of normal tissue rhodanese and endogenous thiosulphate. Thiosulphate is necessary and is the rate limiting factor in the cyanide-thiocyanate pathway. ${ }^{17}$ This may not be so in patients with Leber's optic atrophy or tobacco amblyopia, as they have high cyanide and low thiocyanate levels in their blood. ${ }^{18}$ The dynamics of the thiocyanate-cyanide-thiocyanate system may also be less efficient than we have believed. Vesey et al. ${ }^{13}$ have shown relatively large increases in plasma cyanide levels and relatively small increases in plasma thiocyanate levels following the use of sodium nitroprusside. 


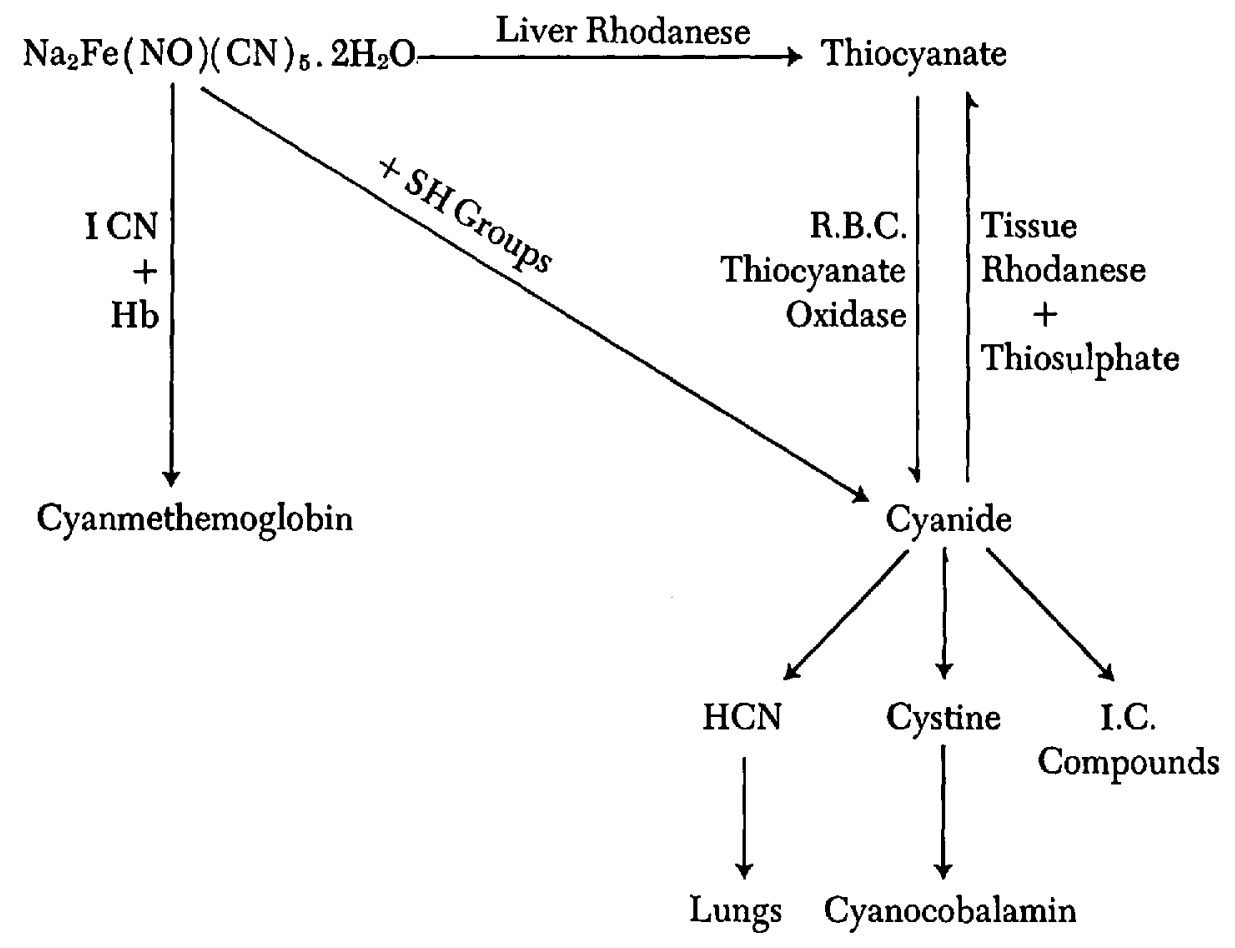

Figure 6. Sodium Nitroprusside-Cyanide Metabolism

\section{Discussion}

It is necessary to relate our various experiences to our understanding of sodium nitroprusside metabolism.

We propose that most healthy patients will have a constant response to a small dose of sodium nitroprusside $(<3 \mathrm{mg} / \mathrm{Kg})$. Others, for reasons presently unknown, will require relatively large doses (in excess of $3 \mathrm{mg} / \mathrm{Kg}$ ) to which they also will show a constant response. These patients show metabolic disturbance in keeping with cellular cyanide intoxication. We suspect that they have a less efficient cyanide-thiocyanate pathway than normal. This may be due to an individual variation in tissue rhodanese activity and/or availability of endogenous thiosulphate.

Those patients resistant to sodium nitroprusside have shown high blood levels of cyanide and inappropriately low levels of thiocyanate indicative of a gross disturbance of the cyanide-thiocyanate pathway. This may be due to an inadequate supply of endogenous thiosulphate, a deficiency or abnormality of tissue rhodanese, an inhibition of tissue rhodanese by other drugs or a combination of these.

Tachyphylaxis to sodium nitroprusside suggests that initially the cyanide-thiocyanate pathway is intact. The exponential-like nature of the increase of drug needed to maintain the same effect suggests the depletion of either endogenous thiosulphate or the increasing inhibition of tissue rhodanese. The metabolic dis- 
turbances accompanying tachyphylaxis and the increase in blood cyanide and decrease in blood thiocyanate levels further support the hypothesis that there is a gradual breakdown of the cyanide-thiocyanate pathway. The dramatic change in tachyphylaxis, the absence of metabolic disturbance, the reduction in blood cyanide and the increase in blood thiocyanate levels in response to sodium nitroprusside following sodium thiosulphate therapy suggest that the tachyphylaxis is due to depletion of endogenous thiosulphate.

\section{ConClusion}

Three responses to sodium nitroprusside as a hypotensive agent during anaesthesia are possible, all of which are noxious to the patient. Consequently, we advocate that the initial response to sodium nitroprusside infusion be monitored very carefully. The projected dose for the anticipated period of hypotension must be calculated from this initial response and, should this exceed $3 \mathrm{mg} / \mathrm{Kg}$, then the sodium nitroprusside should be discontinued and an alternative method used to provide controlled hypotension. Should the initial response show resistance to sodium nitroprusside then the drug should be immediately stopped, for to continue will likely kill the patient of cyanide poisoning. Gradually appearing tachyphylaxis may be treated with an infusion of sodium thiosulphate $150 \mathrm{mg} / \mathrm{Kg}$ over $15 \mathrm{~min}$ utes. This should be followed by a marked reduction of the tachyphylaxis and a return of normal $A-B, P_{\mathrm{O}_{2}}$ and $\mathrm{a}-\mathrm{vD}_{\mathrm{O}_{2}}$ indices. If this does not occur, then sodium nitroprusside should be stopped. Sodium nitroprusside is definitely contraindicated in patients with Leber's hereditary optic atrophy or tobacco amblyopia.

Further studies of the metabolic response to sodium nitroprusside and the accompanying changes in blood cyanide and thiocyanate levels are continuing and will be reported on more fully in the future. This preliminary report is written to draw attention to the abnormal responses which may occur when using sodium nitroprusside and to encourage others to report and investigate these uncommon but potentially dangerous abnormal occurrences.

\section{SUMMARY}

Three different responses to sodium nitroprusside as a hypotensive agent during anaesthesia in children are described. A constant high dose $(>3 \mathrm{mg} / \mathrm{Kg})$ response to, abnormal resistance to and tachyphylaxis to the drug are recognised and are dangerous and potentially lethal. They are probably related to abnormalities of cyanide-thiocyanate metabolism resulting in cyanide accumulation. The abnormal responses produce metabolic acidosis, an increase in mixed venous oxygen tension and a decrease in arterial-mixed venous oxygen content difference. Tachyphylaxis may be due to depletion of endogenous thiosulphate and was reversible by sodium thiosulphate therapy $(150 \mathrm{mgm} / \mathrm{Kg})$ in two cases in which it was used.

\section{RÉSUMÉ}

Notre expérience avec le Nitroprussiate de $\mathrm{Na}$, chez les enfants, nous a permis de classifier les patients selon leur réponse à cet agent. 
Un groupe de patients a une réponse adéquate avec une dose totale plus petite que $3 \mathrm{mg} / \mathrm{kg}$.

D'autres requièrent une dose élevée constante conduisant à une dose totale plus grande que $3 \mathrm{mg} / \mathrm{kg}$. Chez d'autres patients il y a résistance anormale au Nitroprussiate. Enfin, l'apparition d'une tachyphylaxie est observée dans un dernier groupe de patients.

Les réponses observées chez ces trois derniers groupes de patients sont probablement liées à un métabolisme anormal de l'agent avec accumulation de cyanure. Il y a alors production d'acidose métabolique, le $\mathrm{P}_{\mathrm{O}_{2}}$ du sang veineux mixte s'élève, et la différence artério-veineuse en oxygène diminue.

Une déplétion du thiocyanate endogène peut conduire à une tachyphylaxie. De fait on a pu renverser une tachyphylaxie chez deux enfants en administrant du thiocyanate de sodium à la dose de $150 \mathrm{mg} / \mathrm{kg}$.

\section{REFERENCES}

1. Johnson, C.C. The actions and toxicity of sodium nitroprusside. Arch. Int. Pharmacodyn. Ther. 35: 480-496 (1929).

2. Moraca, P.P., Bitte, E.M., \& Hale, D.E., et al. Clinical evaluation of sodium nitroprusside as a hypotensive agent. Anesthesiology 23: 193-199 (1962).

3. Jones, G.O.M. \& Cole, P. Sodium nitroprusside as a hypotensive agent. Br. J. Anaes. 40: 804-805 (1968).

4. Page, I.H., Corconan, A.C., \& Dustan, H.P., et al. Cardiovascular actions of sodium nitroprusside in animals and hypertensive patients. Circulation 11: 188-198 (1955).

5. McDowall, D.G., Keaney, N.P., Tunner, J.M., \& Okuda, Y. The toxicity of sodium nitroprusside. Br. J. Anaes. 46: 327 ( 1974).

6. Merrifield, A.J. \& Blundell, M.D. Toxicity of sodium nitroprusside. Br. J. Anaes. 46: 324 ( 1974$)$.

7. Davies, D.W., Kadar, D., Steward, D.J., \& Munro, I.R. A sudden death associated with hypotensive anaesthesia using sodium nitroprusside. C.A.S.J. (In press).

8. JACK, R.D. Toxicity of sodium nitroprusside. Br. J. Anaes. 46: 952 ( 1974 ).

9. Davies, D.W. \& Munro, I.R. The anaesthetic management and intraoperative care of patients undergoing major facial osteotomies. Plastic and Reconstructive Surg. 55: 50 (1975).

10. Eppens, H. Sodium nitroprusside in hypotensive anaesthesia. Br. J. Anaes. 45: 124 (1973).

11. Lowson, J.A. Sodium nitroprusside in hypotensive anaesthesia. Br. J. Anaes. 44: 980 (1972).

12. Tayloh, T.H., Styles, M., \& Lamanc, A.J. Sodium nitroprusside as a hypotensive agent in general anaesthesia. Br. J. Anaes. 42; 859 (1970).

13. SMith, R.P. \& KRuszyna, H. Nitroprusside produces cyanide poisoning via a reaction with hemoglobin. J. Pharmacol. Exper. Ther. 191: 557 (1974).

14. Vesey, C.J., Cole, P.V., \& Linnel, J.C., et al. Some metabolic effects of sodium nitroprusside in man. Br. Med. J. 2: 140-142 (1974).

15. Epstein, J. Estimation of microquantities of cyanide. Anal. Chem. 19: 272 (1947).

16. Boxer, G.E. \& Rickards, J.C. Chemico-evaluation of vitamin B $_{12}$. Part II. The quantitative isolation of colorimetric determination of millimicrogram quantities of cyanide. Arch. Biochem. Biophys. 30: 372-381 (1951).

17. Williams, R.T. Detoxication mechanisms. Chapman and Hall Ltd., London (1959),

18. WILSON, L. Leber's hereditary optic atrophy: a possible defect of cyanide metabolism. Clin. Sci. 29: 505-515 (1965). 